\title{
Maternal grief
}

Hilkka Laakso and Marita Paunonen-IImonen, Department of Nursing Science, University of Tampere, Tampere, Finland

\begin{abstract}
The purpose of the present study was to analyse maternal grief and coping with grief following the death of a child aged under 7 years. The aim was to obtain information to understand mothers' grief, in order to support them after the death of their child. Data were collected through surveys $(n=91)$. The questionnaire used contained an existing grief reactions checklist and open-ended questions. The data were analysed using a twoway analysis of variance, cross-tabulation and content analysis. The results indicate that the mother's grief was associated with the time elapsed since the child's death. The grief was also associated with the mother's age so that older mothers tended to display more grief reactions of a certain kind (detachment and disorganization) than younger mothers. Younger mothers experienced more personal growth than older ones. The child's age at death was associated with more disorganization among mothers if the child had been aged over 1 year at the time of death. The number of children was also associated with the mother's grief. Mothers displayed more detachment if there were other children in the family than if the child had been an only child.
\end{abstract}

Key words: coping with grief; death of child; maternal grief

\section{Grief caused by the death of a child}

All parents have hopes and dreams of the future of their children. A child is a natural source of selfesteem for parents. When a child dies, the family's hopes and dreams die too. The death of a child insults the parents' ability to act as parents. Guilt and self-blame are associated with all losses but especially with the death of a child (Siltala, 1985; Stewart, 1995).

Different cultures and religions deem the death of a child a distressing or problematic issue. Parents' grief following the death of a child may be more severe, complex and of longer duration than that caused by other losses (Back, 1991; Johnson et al., 1993; Harmanen, 1997). The grief of fathers may be complicated by the fact that society expects men to be strong and that men's expressions of grief are not socially acceptable. Following the death of a child, the father is often asked how his wife is coping with grief, and the man may feel left out (Moriarty et al., 1996; Thomas, 1995).

\footnotetext{
Address for correspondence: M Paunonen-Ilmonen, Department of Nursing Science, University of Tampere, Tampere, Finland. E-mail: hilkka.laakso@pp.inet.fi
}

\section{Definition of grief}

Grief is a reaction to a perceived loss (Cowles, 1996). It is a deep and lasting feeling of distress and pain experienced by a grieving person after the loss of a close person. Although many aberrant features are connected to grief, it has to be considered a normal human feeling (Achté, 1978; Kyyrönen, 1986). Grief is generally regarded as a negative feeling, but it may also entail positive things, such as an opportunity for maturation and discovering new possibilities in life (Mathur, 1995). Spinoza (1989) sees grief as a feeling that diminishes physical and psychological vitality. Conflicts, pain, disappointment and depression undermine vitality and can arrest development unless overcome. For Spinoza, joy as opposed to grief means self-development.

Freud (1978) sees grief as a reaction induced by the loss of a loved one, which is not a pathological condition and does not involve medical treatment. Grief may also find expression in abnormal behaviour, distortion of human relations and physical and mental illness (Callahan and Burnette, 1989; Lieberman, 1978; Miles and Demi, 1994; Osterweis et al., 1984; Parkes and Brown, 1972). 


\section{Grief and mourning in different cultures}

The child's death touches all mothers in a similar way, but every mother has a different way of mourning. Grief is strongly affected by the mother's and family's culture, the mourner's personality, lifestyle and human relations. The experience of grief is the same for all people, but the manifestation of grief, mourning, that is behaviour induced by loss, varies between cultures (Cowles, 1996; Feifel, 1994; Imara, 1983).

Crying is an essential component of grief and mourning. Multicultural research shows that there are few differences between the sexes when it comes to expressing grief through crying. In cultures in which differences were found, women cried more. In a traditional social system men tend to resort to direct action, that is seek help, whereas women resort to indirect action, that is crying, when in need of help (Rosenblatt et al., 1976; Thomas, 1995).

For centuries, the events related to dying have been alleviated by means of various rites and rituals, seeking help from others in the face of a common fear. The fear of loneliness and anxiety may have decreased when the grieving person and a professional weeper have jointly addressed the feelings of grief (Benoliel, 1994; Hägglund, 1977). People respond to life events with the help of rituals, which are used for expressing that something important and/or sad has happened. Nonverbal communication is typical of rituals: when a person has lost the ability to speak, it is easier simply to act rather than speak (Bolton, 1995). In nearly all cultures, birth and death have been the domain of women's knowledge. Lullabies and wails are women's work and the community's grief is discharged through professional weepers. Women act as midwives and washers of dead bodies (Koivunen, 1998).

Communal traditions of mourning help mourners identify and express their feelings in a socially acceptable way. The fewer forms of expressing grief a community has, the freer but also the more helpless the grieving person is in dealing with loss. Traditions of grief are thus both a burden and a relief to the individual (Nenola, 1994).

\section{The study}

The purpose of the present study was to analyse the mother's grief and coping with grief following the death of a child. The study aimed to generate knowledge to understand the mother's grief, to support her in the situation following the child's death and to ease the mother's and the family's life. The objective was to analyse the manifestations, experiences and duration of maternal grief and to describe and assess how mothers cope with grief and understand the meaning of grief. The results of this study could be applied to health care education, in-service training, nursing practice and primary healthcare.

\section{Sample selection}

The target group consisted of mothers whose children had died aged under 7 years in one hospital district between 1990 and 1994. Since the death of a child is an emotionally and ethically sensitive topic, the study was launched when about 1 year had elapsed since the child's death. The sample consisted of 174 mothers, 168 of whom received the questionnaire: six questionnaires were returned because of unknown address. In all, 91 mothers returned the questionnaire, which yielded a response rate of $54 \%$.

The age of the participating mothers ranged from 20 to 49 years. Three-quarters of the mothers were aged over 30 years. Nearly all the mothers were cohabiting or married and over half lived in urban areas. The cause of the child's death as reported by mothers was in most cases illness, whereas one-quarter of the children had died of other causes. Three-quarters had died under the age of 1 year. In about half of the cases, 3 years or more had elapsed since the child's death (Table 1).

\section{Research method}

The data were analysed using quantitative methods. Surveys are used, for example, for studying behaviour, attitudes, meanings and traits (Paunonen and Vehviläinen-Julkunen, 1997; Polit and Hungler, 1991).

The questionnaire used in the survey contained 11 questions about the respondent's background, the Hogan Grief Reactions Checklist (Hogan, 1988) and 18 open-ended questions concerning the mother's experience of grief and coping with grief. The open-ended questions about background data and grief were formulated for this study. The Hogan Grief Reactions Checklist contains 60 statements on a five-point Likert scale ranging from 0 to 4 (does not describe me at all, sometimes 
Table 1 Background data on mothers and children

\begin{tabular}{|c|c|c|}
\hline Background variable & \multicolumn{2}{|c|}{$\begin{array}{l}\text { Mothers participating } \\
\text { in survey }(n=91)\end{array}$} \\
\hline $\begin{array}{l}\text { Age (years) } \\
20-29 \\
30-39 \\
40-49\end{array}$ & $\begin{array}{l}24 \\
56 \\
11\end{array}$ & $\begin{array}{l}26 \\
62 \\
12\end{array}$ \\
\hline $\begin{array}{l}\text { Marital status } \\
\text { Cohabiting or married } \\
\text { single, widowed, divorced }\end{array}$ & $\begin{array}{r}85 \\
6\end{array}$ & $\begin{array}{r}94 \\
6\end{array}$ \\
\hline $\begin{array}{l}\text { Families place of residence } \\
\text { Rural area } \\
\text { Urban area }\end{array}$ & $\begin{array}{l}36 \\
55\end{array}$ & $\begin{array}{l}40 \\
60\end{array}$ \\
\hline $\begin{array}{l}\text { Child's age at death } \\
\text { Under } 1 \text { year } \\
\text { Over } 1 \text { year }\end{array}$ & $\begin{array}{l}67 \\
24\end{array}$ & $\begin{array}{l}74 \\
26\end{array}$ \\
\hline $\begin{array}{l}\text { Cause of death } \\
\text { Illness } \\
\text { Other }\end{array}$ & $\begin{array}{l}65 \\
23\end{array}$ & $\begin{array}{l}71 \\
25\end{array}$ \\
\hline $\begin{array}{l}\text { Elapsed time since child's } \\
\text { death } \\
\text { Less than } 3 \text { years } \\
3 \text { years or over }\end{array}$ & $\begin{array}{l}42 \\
47\end{array}$ & $\begin{array}{l}47 \\
52\end{array}$ \\
\hline $\begin{array}{l}\text { Siblings } \\
\text { Yes } \\
\text { No }\end{array}$ & $\begin{array}{l}55 \\
34\end{array}$ & $\begin{array}{l}62 \\
38\end{array}$ \\
\hline
\end{tabular}

describes me, describes me pretty well, describes me well, describes me very well). The instrument's statements have been categorized under the following six groups of variables: despair, 13 variables (e.g., hopelessness, sadness, loss); panic behaviour, 14 variables (e.g., fatigue, headache, abdominal pain); personal growth, 10 variables (e.g., forgiveness, tolerance, hope); blame and anger, seven variables (e.g., bitterness, hostility, revenge); detachment, eight variables (e.g., avoidance of tenderness or of other people); and disorganization, eight variables (e.g., difficulty concentrating and learning new things). Personal growth was the only group that addressed positive experiences. Here are some examples of the statements in the different groups of variables. Personal growth: learned to cope better with life, stronger because of grief, reached a turning point where I began to let go of some of the grief, I am having more good days than bad; Detachment: confusion about who I am, feeling unable to cope, feeling detached from others; Disorganization: forget names and telephone numbers easily, impaired long-term memory; difficulty learning new things, tasks seem insurmountable.

The open-ended questions asked mothers to describe the worst thing about the grief caused by the child's death; from what and from whom they received or wanted to receive help; what sort of help and support they received from professional practitioners and how work and hobbies affected their coping with grief.

\section{Ethical considerations}

The research plan was approved by a local Ethics Committee. Mothers whose child had died at least 1 year previously were selected for the survey. The timing of the study and the study's effects on study subjects are issues that have to be carefully considered while studying a sensitive topic (Cowles, 1988; Marshall and Rossman, 1995). Data collection must not cause suffering or harm to informants in any phase of the study (Fontana and Frey, 1994; Polit and Hungler, 1991). Confidentiality of data was assured by not coding the questionnaires and by not requesting detailed background data of respondents. It was thus impossible to identify respondents or nonrespondents. This had no bearing in this study as it had been decided not to send reminders to nonrespondents because of the sensitive nature of the study. Polit and Hungler (1991) suggest that surveys provide the possibility of complete anonymity. The effect of nonresponse on the results was assumed to be of minor importance.

\section{Reliability}

The reliability of a survey was assessed based on the instrument used and on the target group and analysis of the study. The reliability of the Hogan Grief Reactions Checklist (Hogan, 1988) was tested using Cronbach's alpha coefficients. The value of the alpha coefficient ranged between 0.66 and 0.84 . The values were thus relatively high and the removal of any of the variables would not have improved them. Other studies employing the same instrument have yielded alpha coefficients ranging from 0.67 to 0.83 (Hyrkäs et al., 1997) and 0.79 to 0.90 (Hogan et al., 2001). The Grief Reactions Checklist was translated from English into Finnish, back into English and then again into Finnish. Triple translation enhanced the correspondence and 
comparability of the concepts of the instrument in different languages. When translating an instrument, it is necessary to have a good command of language and knowledge of the content of the instrument (Bernard, 1988; White and Erlander, 1992). Differences between American and Finnish cultures were recognized while developing the instrument, but it was assumed that the differences found would not be an obstacle to its use.

The starting point and precondition for sample selection was that the informants had a personal experience of the death of a child (Hirsjärvi and Hurme, 1984; Pyörälä, 1994). The nature of the selected data is associated with their reliability, and facts provide the most reliable source of data (Alkula et al., 1995). Children aged under 7 years were selected for the study, since in this age group the impact of home and family is of central importance and the children can thus be thought of as a unified group. The criterion for inclusion in the study was that a minimum of 1 year had elapsed since the child's death, because it may be hard to talk about the death of a child to a stranger and a survey conducted at an earlier date could have lowered mothers' participation in the study. Data collection in international studies of the same topic occurred 1 to 2 months after the child's death (Boyle etal., 1996; Dyregrov and Matthiesen, 1991; Khalaf, 1989; Vance et al., 1995).

It was impossible to assess the effect of the time elapsed from the child's death on the mothers' willingness to participate in the study, but it can be assumed that after a year mothers are more emotionally stable than before and thus better able to answer research questions and analyse their own sentiments. Sixty-seven per cent of the mothers were aged 30 years or older. The age distribution of the mothers cannot be explained based on the results, but it could be assumed that the sample reflects the relatively high average age of childbearing among Finnish women. It is also possible that various pregnancy disorders were a major cause of death $67 \%$ of the children died under the age of 1 year and in $65 \%$ of the cases the cause of death was illness) as older mothers are known to have more disorders than younger ones.

The results of this study are mainly compared with those generated by Hogan as the study used Hogan's instrument and a number of similar results serve to confirm the instrument's reliability.

\section{Analysis}

A two-way analysis of variance, a Wilcoxon test, cross-tabulation and content analysis for openended questions were used to analyse the data. An analysis of variance was used to establish the interactions of the independent variables. Sum variables were formed of the variables in the grief reactions checklist, and interactions between them and respondents' background data were sought. The association between the variables formed of the open-ended questions and sum variables was examined using a Wilcoxon test. The data were analysed using SPSS/Win 7.0 statistical programme. The results are presented as frequency and percentage distributions, means and statistical significance $(P<0.1=$ statistically suggestive; $P$ $<0.05=$ nearly statistically significant; $P<0.01$ $=$ statistically significant $P<0.001=$ statisti cally significant).

\section{Results}

\section{Connection between grief reactions and background variables}

The interactions between grief reactions and background variables showed that the time that had elapsed since the child's death was associated with the manifestation of the mother's grief so that mothers displayed despair, felt more blame and anger and detachment if less than 3 years had elapsed since the child's death. Older mothers (3049 years) displayed more detachment and disorganization than younger mothers (20-29 years), whereas younger mothers displayed more personal growth than older mothers. If the child was aged over 1 year at death, mothers displayed more detachment than if the child had died aged under 1 year. If there were other children in the family, mothers displayed more detachment than if the child had been an only child.

The interactions between the background variables were also related to the manifestation of the mother's grief. For example, the mothers' age, the number of children in the family and cause of death in combination with the elapsed time since the death were associated with the despair: older mothers (30-49 years) displayed more despair if less than 3 years had elapsed since the child's death. Mothers also displayed more despair if less than 3 years had elapsed since the child's death 
and if there were other children in the family or if the cause of death was other than illness.

Older mothers displayed more panic behaviour if they had other children or if less than 3 years had elapsed since the child's death. Those mothers whose child had died less than 3 years ago and who had other children also displayed more panic behaviour.

Younger mothers displayed personal growth if the child had been aged under 1 year at the time of death or if less than 3 years had elapsed since the death. Mothers as a whole displayed more personal growth if the child had died over 3 years ago, the child was aged over 1 year at death or if the cause of death was other than illness.

The study yielded the following results as a result of the interaction between several variables: mothers displayed more blame, anger and detachment if less than 3 years had elapsed since the child's death and the family had other children or if the cause of death was other than illness. Mothers displayed more disorganization if the child had died from causes other than illness and he or she had been aged over 1 year at the time of death or there were other children in the family and less than 3 years had elapsed since the child's death.

\section{Connection between open-ended questions and background variables}

The open-ended survey questions charted the help and support received by mothers and their coping with grief. The mothers displaying more despair than other mothers had gained the most relief from work, hobbies, studying and their significant others. Despair was also manifested in a need to talk about the grief and in a wish to find someone who would listen and take care of them. The mothers reporting less despair had received professional help and felt that this had strengthened their self-esteem. Other people's negative attitudes were considered the worst thing about grief.

The mothers displaying more panic behaviour than other mothers reported having feelings of loneliness, emptiness and fear. They had received help from professional helpers, they would have wanted to talk about their grief and expressed the need to consult a doctor. These mothers had received little help from hospital staff and were unable to return to work after the child's death.

Personal growth was reported by mothers who had received help from their significant others and felt that the grief had strengthened their selfesteem. These mothers reported that other people had showed a negative attitude towards the child's death and experienced grief, longing and pain. The mothers manifesting less personal growth had received professional help and wanted to share their grief with another person.

The mothers displaying less blame and anger than other mothers experienced feelings of loneliness, emptiness and fear. They had received professional help and wanted to talk about the death of their child. They needed support from a doctor and fellow sufferers. The mothers displaying less blame and anger had received support from their significant others and felt that their self-esteem was stronger because of that.

The mothers experiencing more detachment had received support from professional helpers and grief support groups. They felt a need to talk about the death of their child and to consult a doctor. The mothers displaying less detachment had received help from their significant others, but while still in hospital, they reported having needed more support from others rather than just from the nursing staff.

The mothers experiencing more disorganization had received professional help and they would have wanted to consult a doctor for support and talk about the death of their child. The mothers experiencing less disorganization had received grief support from their significant others.

\section{Discussion}

This study found the following statistically significant or statistically suggestive manifestations of grief among mothers: despair, personal growth, blame and anger, detachment and disorganization (see Table 2). Despair was related to the cause of the child's death: when the cause of death was sudden infant death or drowning, mothers displayed more despair. A sudden death of a child is often considered more difficult to cope with than that caused by illness, because a sudden death does not leave mothers time to prepare themselves for the death (Back, 1991; Demi and Miles, 1994; Khalaf, 1989; Lang and Gottlieb, 1993; Siltala, 1985). Hogan et al. (2001) found, however, that the despair (e.g., hopelessness, sadness, loss) caused by the death of a child does not differ from that caused by a sudden death. 
Table 2 Connections between mothers' grief reactions and background variables $(n=91)$

\begin{tabular}{llll}
\hline Grief reaction & Background variable & Statistical significance & $n$ \\
\hline Despair & Less than 3 years since death & $P=0.003$ & 42 \\
Personal growth & Younger mothers (20-29 years) & $P=0.067^{\mathrm{a}}$ & 24 \\
Blame and anger & Less than 3 year since death & $P=0.034$ & 42 \\
Detachment & Older mothers (30-49 years) & $P=0.071^{\mathrm{a}}$ & 67 \\
Detachment & Less than 3 years since death & $P=0.065^{\mathrm{a}}$ & 42 \\
Detachment & Other children in the family & $P=0.055^{\mathrm{a}}$ & 55 \\
Disorganization & Older mothers (30-49 years) & $P=0.007$ & 67 \\
Disorganization & Child aged over 1 year at death & $P=0.069^{\mathrm{a}}$ & 24 \\
\hline
\end{tabular}

${ }^{a}$ The result is not statistically significant but can be considered statistically suggestive.

Mothers also displayed more despair when there were other children in the family, which may suggest that they did not have the time or space for grief work, an explanation supported by Gilbert and Smart (1992). Parkes (1986), on the other hand, suggested that children may support the grieving parents and Zeanah et al. (1995) indicated that other children in the family reduced mothers' despair.

The most intense period of grief usually lasts about a year, during which the grieving person experiences all the seasons and important events of the year for the first time without the deceased person (Härkönen, 1989). Imara (1983) indicated that the average length of grief is 2 years, whereas McGlowry et al. (1987) suggested that many parents felt pain and a sense of loss 7 to 9 years after their child's death.

It is thus not possible to determine the exact duration of grief. One indication of recovery might be that the grieving person is able to think about the deceased without pain. Matters such as the grieving person's relationship with the deceased, earlier losses, material and emotional dependence on the deceased person, the age of the grieving person and of the deceased, and religion and culture all have an effect on the duration of grief (Imara, 1983; Miles and Demi, 1992; Ostfeld et al., 1993; Worden, 1988).

As for the elapsed time since the child's death, Hogan et al.'s (2001) study yielded findings similar to those generated by our study. If less than 3 years had elapsed from the child's death, then the parents displayed more despair than if the child had died more than 3 years previously. Hogan et al. (2001) found that mothers displayed significantly more panic behaviour (e.g., fatigue, headache, abdominal pain) if less than 3 years had elapsed from the child's death. No association was found between grief reactions and the elapsed time since the child's death. Hogan et al. (2001) suggested that the parents of a child who had committed suicide or suffered a violent death displayed more panic behaviour than those parents whose child had died of illness. No differences were found in the time elapsed since the child's death.

Personal growth (forgiveness, tolerance, hope) was related to the mother's age: younger mothers experienced more personal growth than older mothers. Hogan et al. (2001) examined personal growth in relation to the elapsed time since the child's death: if more than 3 years had elapsed, then the mothers displayed more personal growth than the other mothers studied.

When less than 3 years had elapsed since the child's death, mothers displayed more blame and anger (e.g., bitterness, hostility, revenge). According to Hogan et al. (2001), mothers displayed more blame and anger if the child had suffered a violent death than if the death was classified as some other cause of death. This study divided the causes of death as reported by mothers into illnesses or other causes. Our study included at least three children who had suffered a violent death, but these are examined as other causes.

Detachment (e.g., avoidance of tenderness and of other people) was associated with the mother's age (older mothers), elapsed time since the child's death (less than 3 years) and other children (other children in the family).

Mothers displayed more disorganization (e.g., difficulty concentrating and learning new things) if the child was older than 1 year at the time of death. Hogan et al. (2001) found that the features of dis- 
organization were associated with the time elapsed since the child's death: if less than 3 years had elapsed, mothers displayed significantly more disorganization.

Mothers' feelings of grief had physical, psychological and social manifestations. Physical responses involved pain, distress and fatigue. Psychological responses included depression, a sense of failure, guilt and anger. Social responses included fear of loneliness, need for loneliness support and a feeling of emptiness. Similar findings have been reported by Cullberg (1966), Dyregrov and Matthiesen (1991), Martinson et al. (1991), Vance et al. (1995) and Moriarty et al. (1996).

Mothers' grief was highly individualized, as is also indicated by Imara (1983), Achté et al. (1985), Moltmann (1995), Cowles (1996) and Väisänen (1996). On the other hand, the experience of grief was very similar for most mothers, as stated by Moriarty et al. (1996). As a phenomenon, the death of a child touches all mothers in a similar way, but every mother has a different way of dealing with grief, because this is greatly affected by the mother's and family's culture, the mourner's personality, lifestyle and family relations (Cowles, 1996; Saiki et al., 1994). Moriarty et al. (1996) suggested that socio-economic and financial status or educational attainment do not cause differences in how mothers experience grief. Mothers' grief following the death of a child also involved positive feelings, such as joy induced by the termination of the child's suffering, and relief and happiness. For example, studies by Imara (1983), Mathur (1995), Moltmann (1995) and Cowles (1996) have addressed grief-related positive feelings.

\section{Conclusions}

Mothers' grief after the death of a child had physical, psychological and social manifestations. Thus, their grief reactions varied greatly. The time elapsed since the child's death (less or more than 3 years), cause of child's death (illness or some other cause), the mother's age (20-29 or 30-49 years) and the child's age at death (under or over 1 year) were associated with the manifestations of the mother's grief.

The results indicated that mothers were not sufficiently heard in matters concerning the child, that they did not receive enough information and counselling, and that their contact with the hospital or health centre ended after the child's death. The quality of care could be improved by listening to the mothers and families affected by the death of a child. The lack of information and support experienced by mothers could be remedied by increasing the staff's knowledge, by improving collaboration and internal communication and by clarifying the division of labour and responsibility. Since attending to death and grieving people is a demanding task, the staff's professional skill should be continuously developed after post-basic education. Attention to the staff's knowledge and various supportive measures, such as clinical supervision, and proper staffing and work environment would enhance their capacity to care for dying children and support grieving mothers. Continuous self-assessment of work and mutual support would facilitate the staff's coping with this psychologically demanding and difficult task.

\section{References}

Achté, K. 1978: Psykologiaa lääketieteessä. (Psychology in medicine.) In Viitamäki, R.O., Achté, K.A. and Rechardt, E., editors. Kliininen psykologia. Helsinki: WSOY, 245-324.

Achté, K., Vauhkonen, M-L., Lindfors, O. and Salokari, M. 1985: Syöpä elämän kriisinä. (Cancer as a life crisis). Helsinki: Otava.

Alkula, T., Pöntinen, S. and Ylöstalo, P. 1995: Sosiaalitutkimuksen kvantitatiiviset menetelmät (Quantitative methods in social research). Helsinki: WSOY.

Back, K.J. 1991: Sudden, unexpected pediatric death: caring for the parents. Pediatric Nursing 17, 571-5.

Benoliel, J.Q. 1994: Death and dying as a field of inquiry. In Corless, I.B., Germino, B.B. and Pittman, M., editors. Dying, death and bereavement. Theoretical perspectives and other ways of knowing. London: Jones and Bartlett Publishers, 3-14.

Bernard, H.R. 1988: Research methods in cultural anthropology. London: Sage.

Bolton, D. 1995: The role of ritual, symbols and meanings in psychological and community adjustment following civil conflict. In Lundin, T. editor. Grief and bereavement. Proceedings from the Fourth International Conference on Grief and Bereavement in Contemporary Society, Stockholm. Stockholm: Swedish National Association for Mental Health, 1-8.

Boyle, F.M., Vance, J.C., Najman, J.M. and Thearle, M.J. 1996: The mental health impact of stillbirth, neonatal death or sids: prevalence and patterns of distress among mothers. Social Science of Medicine 43, 1273-82.

Callahan, E.J. and Burnette, M.M. 1989: Intervention for pathological grieving. The Behavior Therapist 12, 153-7. 
Cowles, K.V. 1988: Issues in qualitative research on sensitive topics. Western Journal of Nursing Research 10, 163-79.

Cowles, K.V. 1996: Cultural perspectives of grief: an expanded concept analysis. Journal of Advanced Nursing 23, 287-94.

Cullberg, J. 1966: Reaktioner inför perinatal barnadöd (I). Psykiska följder hos kvinnan. Läkartidningen 63, 3980-6.

Demi, A.S. and Miles, M.S. 1994: Bereavement guilt. A conceptual model with applications. In Corless, I.B., Germino, B.B. and Pittman, M., editors. Dying, death and bereavement. Theoretical perspectives and other ways of knowing. London: Jones and Barlett Publishers, 171-88.

Dyregrov, A. and Matthiesen, S.B. 1991: Parental grief following the death of an infant - a follow-up over one year. Scandinavian Journal of Psychology 32, 193-207.

Feifel, H. 1994: Attitudes toward death: a personal perspective. In Corless, I.B., Germino, B.B. and Pittman, M., editors. Dying, death and bereavement. Theoretical perspectives and other ways of knowing. London: Jones and Barlett Publishers, 49-60.

Fontana, A. and Frey, J.H. 1994: Interviewing. The art of science. In Denzin, N.K. and Lincoln, Y.S. editors. Handbook of qualitative research. London: Sage, 361-76.

Freud, S. 1978: Mourning and melancholia. In Strachey, J. editor. The standard edition of the complete psychological works of Sigmund Freud 14:243-58. London: Hogarth Press, 239-60 (original publication in 1917).

Gilbert, K.R. and Smart, L.S. 1992: Coping with infant or fetal loss. The couple's healing process. New York: Brunner/Mazel Psychosocial stress series No 22.

Hägglund, T.-B. 1977: Lähestyvä kuolema. (Approaching death). Duodecim 93, 835-44.

Härkönen, L. 1989: Lähestyvä kuolema. (Impending death). Helsinki: WSOY.

Harmanen, E. 1997: Sielunhoito sururyhmässä. Tutkimus ryhmän ohjaajan näkökulmasta Suomen evankelis-luterilaisessa kirkossa. (Pastoral care in a grief support group. A study of a group facilitator's perspective in the Finnish EvangelicalLutheran Church). Helsinki: Suomalaisen teologisen kirjallisuusseuran julkaisuja 207.

Hirsjärvi, S. and Hurme, H. 1984: Merkityksen ongelma haastattelututkimuksessa. (The problem of meaning in research interviews). Jyväskylä: Jyväskylän yliopiston kasvatustieteen laitoksen julkaisuja A3.

Hogan, N.S. 1988: Factor structure for the Hogan Grief Reactions Checklist manual. Miami, FL.

Hogan, N.S., Greenfield, D.B. and Schmidt, L.A. 2001 : Development and validation of the Hogan Grief Reaction Checklist. Death Studies 25, 1-32.

Hyrkäs, K., Kaunonen, M. and Paunonen, M. 1997: Recovering from the death of a spouse. Journal of Advanced Nursing 25, 775-9.

Imara, M. 1983: Growing through grief. In Corr, C.A. and ja Corr, D.M. editors. Hospice care. Principles and practice. Springer, New York, 249-265.

Jacob, S.R. 1993: An analysis of the concept of grief. Journal of Advanced Nursing 18, 1787-94.

Johnson, L.C., Rincon, B., Gaber, C. and Rexin, D. 1993: The development of a comprehensive bereavement program to assist families experiencing pediatric loss. Journal of Pediatric Nursing 8, 142-46.

Khalaf, I.A. 1989: The relationship between the type of the child's death whether anticipated or unexpected and the Jordanian mother's grief responses. New York University.

Koivunen, H. 1998: Hiljainen tieto (tacit knowledge). 2nd ed. Helsinki: Otava.

Kyyrönen, K. 1986: Suru (grief). In Aalto, K. editor. Saattohoito. Helsinki: WSOY, 119-35.

Lang, A. and Gottlieb, L. 1993: Parental grief reactions and marital intimacy following infant death. Death Studies 17, 233-55.

Lieberman, S. 1978: Nineteen cases of morbid grief. British Journal of Psychiatry 132, 159-63.

Marshall, C. and Rossman, G.B. 1995: Designing qualitative research. London: Sage.

Martinson, I.M., Davies, B. and McClowry, S. 1991: Parental depression following the death of a child. Death Studies 15, 259-67.

Mathur, A. 1995: Menetyksen psykodynamiikka: Kyky luopua kyky elää (Psycho-dynamics of loss: ability to give up - ability to live). Suomen Lääkärilehti 50, 2084-9.

McGlowry, S.G., Davies, E.B., Kulenkamp, E.J. and Martinson, I.M. 1987: The empty space phenomenon: the process of grief in the bereaved family. Death Studies 11, 361-74.

Miles, M.S. and Demi, A.S. 1992: A comparison of guilt in bereaved parents whose children died by suicide, accident or chronic disease. OMEGA 24, 203-15.

Miles, M.S. and Demi, A.S. 1994: Historical and contemporary theories of grief. In Corless, I.B., Germino, B.B. and Pittman, M. editors. Dying, death and bereavement. Theoretical perspectives and other ways of knowing. London: Jones and Barlett Publishers, 83-106.

Moltmann, J. 1995: On grief and consolation in modern society. In Lundin, T. editor. Grief and bereavement. Proceedings from the Fourth International Conference on Grief and Bereavement in Contemporary Society. Stockholm: Swedish National Association for Mental Health, 1-11.

Moriarty, H.J., Carroll, R. and Cotroneo, M. 1996: Differences in bereavement reactions within couples following death of a child. Research in Nursing and Health 19, 461-9.

Nenola, A. 1994: Suremisen perinteistä (traditions of grief). In Suominen, T., Hupli, M., Iire, L. and Leino-Kilpi, H. editors. Hoitotiede 1994. Helsinki: Pro Nursing ry:n vuosikirja, 98106.

Osterweis, M., Solomon, F. and Green, M. editors. 1984: Bereavement, reactions, consequences and care. Washington D.C.: National Academy Press.

Ostfeld, B.M., Ryan, T., Hiatt, M. and Hegyi, T. 1993: Maternal grief after sudden death syndrome. Developmental and Behavioral Pediatrics 14, 156-62.

Parkes, C.M. and Brown, R.J. 1972: Health after bereavement. A controlled study of young Boston widows and widowers. Psychosomatic Medicine 34, 449-61.

Parkes, C.M. 1986: Bereavement. Studies of grief in adult life. 2nd ed. London: Tavistock Publications.

Primary Health Care Research and Development 2002; 3: 115-123 
Paunonen, M. and Vehviläinen-Julkunen, K. 1997: Tutkimussuunnitelman laadinta kvantitatiivisessa ja kvalitatiivisessa tutkimuksessa (Devising a research plan for quantitative and qualitative research). In Paunonen, M. and VehviläinenJulkunen, K., editors. Hoitotieteen tutkimusmetodiikka. Helsinki: WSOY, 36-48.

Polit, D.F. and Hungler, B.P. 1991: Nursing research. Principles and methods. Philadelphia: Lippincott.

Pyörälä, E. 1994: Kvalitatiivisen terveystutkimuksen metodologisia perusteita (Methodological bases of qualitative health research). Sosiaalilääketieteellinen Aikakauslehti 31, 4-14.

Rosenblatt, P.C., Walsh, R.P. and Jackson, D.A. 1976: Grief and mourning in cross-cultural perspective. New Haven, CT: HRAF Press.

Saiki, S.C., Martinson, I.M. and Inano, M. 1994: Japanese families who have lost children to cancer: a primary study. Journal of Pediatric Nursing 9, 239-50.

Siltala, P. 1985: Omaisten surutyö (Grief work among significant others). In Ruth, J.-E. and Heiskanen, P. editors. Kuolema elämän keskellä. Helsinki: Otava, 167-84.

Spinoza, B. 1989: Etiken. Bokförlaget. Stockholm: Thales.
Stewart, E.S. 1995: Family-centered care for the bereaved. Pediatric Nursing 21, 181-7.

Thomas, J. 1995: The effects on the family of miscarriage, termination for abnormality, stillbirth and neonatal death. Child: Care, Health and Development 21, 413-24.

Vance, J.C., Boyle, F.M., Najman, J.M. and Thearle, J.M. 1995: Gender differences in parental psychological distress following perinatal death or sudden infant death syndrome. British Journal of Psychiatry 167, 806-11.

Väisänen, L. 1996: Family grief and recovery process when a baby dies. A qualitative study of family grief and healing processes after fetal or baby loss. Oulu: Acta Universitatis Ouluensis D 398.

White, M. and Elander, G. 1992: Translation of an instrument. Scandinavian Journal of Caring Sciences 6, 161-4.

Worden, W.J. 1988: Grief counselling and grief therapy. London: Routledge.

Zeanah, C.H., Danish, B., Hirschberg, L. and Dietz, L. 1995: Initial adaptation in mothers and fathers following perinatal loss. Infant Mental Health Journal 16, 80-93. 